\title{
An Evaluation of English-to-Yoruba Translations of some Concepts by Selected Radio News Bulletins
}

\author{
Samson Adeyeye Dare and Francis Yede \\ Olabisi Onabanjo University, Ago Iwoye, Nigeria \\ samsonadare@yahoo.co.uk \\ yedefrancis967@gmail.com
}

\begin{abstract}
This study examines translations of selected official names/titles contained in news broadcasts in the Yorubá-speaking part of Nigeria, interrogating their adequacy and appropriateness. Sixty-five concepts/titles extracted from one hundred news bulletins presented by five radio stations across the Yorubá-speaking states of Nigeria are examined. The study is prompted by an intuitive feeling of inaccuracy and inappropriateness of important words in news broadcasts in Yorubá and predicated upon the fact that misinformation can be as pernicious as lack of information. The renderings of the concepts in Yorubá are compared with their original versions in English, revealing translation weaknesses such as semantic narrowing, expansion, wordiness, sometimes even unwitting distortions. It concludes by emphasising the adoption of appropriate translation strategies and a more rigorous engagement with the texts as a way of guarding against unintended distortions and misinformation.
\end{abstract}

\section{Introduction}

One crucial challenge encountered by translators involves accurate transfer of worldviews and socio-political ideologies to the receptor language, a challenge arising because no two languages operate or express issues in the same way and especially because language is culture-specific. The task of translation requires not only a bilingual ability on the part of the translator but also a bi-cultural vision. Translators and interpreters, therefore, are mediators, mediating between cultures (including ideologies, moral systems and socio-political structures), seeking to overcome those incompatibilities which stand in 
the way of transfer of meaning. What has value as a sign in one cultural community may be devoid of significance in another and it is the translator who is uniquely placed to identify the disparity and may seek to resolve it.

Not being a neutral exercise, translation occurs invariably in a context, just as texts emerge in historical contexts. Translations are processed as situation-in-culture exercises. Gentzler (2001) says:

Subjects of a given culture communicate in translated messages primarily determined by local culture constraints. Inescapable infidelity is presumed as a condition of the process; translators do not work in ideal and abstract situations or desire to be innocent, but have vested literary and cultural interests of their own, and want their work to be accepted within another culture. Thus, they manipulate the source text to inform as well as conform to existing cultural constraints (134).

A rewarding approach to translation is a descriptive, target-oriented, functional and systemic one that takes more than a passing interest in the norms and constraints that govern the production and reception of translation. In consonance with this, Lefevere and Bassnett (1990: 89) observe that the study of translation practices has transcended a formalist approach and become involved in the more encompassing issues of context, history and convention. Contextualisation of translation involves culture, politics and power. The concern of translation with the broad matters of socio-political structures and the worldview embedded in the target language provides a useful background to this study.

\section{Statement of the Problem}

Yorubá speakers of English may feel intuitively that certain concepts are not adequately or accurately translated in Yorubá news bulletins. It becomes important to critically examine some translated concepts employed in Yorubá bulletins as a way of interrogating the adequacy and accuracy of the translations. The translation choices adopted by journalists in the Yorubá- speaking part of Nigeria have given birth to such curious interpretations and translations as ile asofin àgbà (the senior/superior law-making chamber, that is, the Senate) and ilé asófin kékeré (the junior law-making chamber, i.e., the House of Representatives). There is also evidence of insufficient lexical and semantic discrimination and differentiation in the translations of different military ranks such as 'Colonel, 'General', 'Admiral', and 'Sergeant' as they are all translated as ogágun (the military boss). This is also the case with the translation of different cadres of Christian religious leaders such as 'Chaplain' and 'Pastor' which 
are indiscriminately translated as ojisé Olórun (the-person-who-delivers-God's message). These illustrations call to question the adequacy and effectiveness of such translations. There is the need, from the foregoing, to study standard practices and translation strategies that characterise press translations among news-writers in South-Western Nigeria.

\section{Language and Culture}

Studies have shown that language and culture are intricately woven together such that any attempt to separate them along parallel lines will only be an exercise in futility. Culture is the totality of the socially acquired knowledge about the way of life of a people and this obviously includes their language. One of the most classical definitions of culture is that of Tylor (1891), as cited by Tschumi (1978), which regards culture as: "that complex whole which includes knowledge, belief, art, law, morals, customs, and all other capabilities and habits acquired by man as a member of society" (236). To Oyeneye and Shoremi (1985), Tylor's definition of culture distinguishes between the acquired qualities of humans and their instinctive qualities. Culture not only refers to artifacts but also ideas, technical knowledge, habits, values, modes of behavior and socialization. Andah (1982) submits that, "culture embraces all the materials and non-material expressions of a people as well as the process with which the expressions are communicated. Indeed, man is a culture-creating and culture-bearing being" (4).

Like culture, language has been defined variously by linguistics scholars. Sapir (1963) defines language as "a purely human and non-instinctive method of communicating ideas, emotions, and desires by means of a system of voluntarily produced symbols" (8). It is clear from this definition that language is an exclusively human possession. As noted earlier, language cannot be discussed to the exclusion of culture. In Sapirs' (1963) view, language has a dual relationship with culture; it is part of culture as well as a major vehicle for the expression of culture (207). Language is therefore central to culture, and as Adetugbo (1992) puts it, "the centrality of language to culture is recognized everywhere" (14). Jessel (1978) also cites Fishman (1972) as saying that language is the medium of culture, both intrinsic and extraneous. Hayakawa (1964) posits that man's cultivated ways of behaving and the internal patterns behind them constitute his culture and are made manifest in his language.

As a consequence of the inter-relatedness of language and culture, bilingualism and multilingualism necessarily imply biculturalism and multiculturalism. Acquiring a language means more than understanding the lexis and structure of the language. It has to do with the knowledge of the cultural patterns of life of the speakers of the language. Our culture influences the way we use language 
to express reality. Culture is the totality of the way we think and behave, which in turn influences our language and the way we use it.

\section{Broadcast News-writing and Translation}

Given the constraints in length and deadline pressure, it is a routine practice in the broadcast newsroom to resort to gist extraction. In analysing the macrostructures and schemata of news discourse, Van Dijk (1998: 20) writes that source texts are usually summarised in the newsroom on a routine basis and television news can be treated as a summarised version of the print news. Bielsa and Bassnett (2009: 52) also highlight condensation as a major requirement in broadcast media editing. In Clausen's (2004: 12) view, the TV / Radio newscast is misrepresenting itself to conclude that it delivers all the day's news. In commercial television stations, lengthy reports have no place and brevity is the rule. This is probably the reason broadcast news-writing is often criticized for pruning down and presenting virtually only the 'bare bones' of the news story, especially when compared to print journalism.

Translators habitually refine their translations as the production progresses. Schank and Abelson (1977) note that "the conscious element that goes into beautifying language is not present in speech" (16). Gambier and Henrik (2001: 110) also believe that the conversational style in radio and television news bears semblance to that of ordinary spoken dialogue. As the broadcast copy is translated to be spoken, it is imperative that the style be more conversational but not at the expense of accuracy (Haji Mohammadi, 2005: 72). Effective broadcast news translators desire to inculcate the habit of telling the story effectively, guided by the understanding that the television viewers / radio listeners have no opportunity go back over the copy.

The source texts are sometimes rough notes based on which target texts are produced; therefore, understanding the logic of the original proves to be of paramount importance, for it facilitates editing and rewriting, as well as routine practices in the newsroom. This brings us to the final product of broadcast news translation where the ultimate goal is to write to speak to people, not read to them and this is the bedrock of the claim that "newspapers communicate with printed words, radio with spoken words and television with spoken words and moving pictures" (Bielsa and Bassnett, 2009: 52).

\section{Strategies for Packaging News in another Language/Culture}

Studies have been carried out on how and why articles and concepts on international news are translated and edited as they are. It should be noted that there are several processing stages between spotting an event in a foreign country and the final news product, printed or broadcast for the readers/ listeners. These stages, as we know, involve translation and editing (or rather 
trans-editing), transforming the language and the structure of the original message by using strategies such as re-organisation, deletion, addition, and substitution (Hursti, 2001).

Earlier, the amount of news flow has been controlled and selected in order to keep the stories or story details, which are considered news worthy to be passed to the next gate. This gate-keeping process depends on how much firsthand knowledge the editor has about the event to be reported and at what stage of the process he is assigned to the event/story or decides to follow it up. The gate-keeping decisions are also governed by the news journalism organisation, the news agencies (concerning news style and readability) and the requirement of speed (time being a key element in the whole process) (Haj Mohammadi 2005: 18). News organizations are embedded in a certain cultural environment. In the light of this, an international news agency cannot pack its news copy with too culture-specific allusions or metaphors. News items must be produced in a way to make a text culturally acceptable everywhere and to all. All the information must be accessible to foreign translators/localisers, regardless of their cultural background.

If we consider the strategies used when transforming news agency source texts, we discover re-organization as a main tool. It is a means to (re)structure the source text: refocusing the information in a given paragraph, moving or permuting some of the details somewhere else in the story. This implies, for instance, permutation of individual lexical items, but also extensive revamping of information at a higher textual level. The re-organisation can be done partly because of differences between languages, rhetoric traditions, and partly to better serve the needs of the news target readership/listeners.

For instance, Akio (1988) speaks of controlling, transforming, supplementing and reorganising messages. What are important, in our opinion, are not so much the number and the label of the strategies but the awareness that international news communication cannot be analysed merely as a matter of isolated news texts. Translation studies have emphasised, in recent decades, the importance of context and contextualisation in the translating process and, in the decisions made by translators.

\section{Framing}

\section{Strategies for News Items Translation}

The media provide frames of reference, or highly stereotyped representations of specific situations, to make the event accessible to the public. They shape other kinds of frames - the ones that the audience, the individuals use when interpreting information about events. The frame systems consist of 
stereotypical scenarios, routines, and beliefs, and are based on expectations in a given social situation. They enable each of us 'to locate, perceive, identify and label' (Fillmore, 1977, Dubois, 1997, Goffman, 1974, Schank, et al. 1977). Media frames or news frames focus on what is discussed and how it is discussed or not. They are embodied in the keywords, metaphors, concepts, symbols, visual images used in a news narrative (Entman, 1991).

Through the framing of a news discourse, journalists and their editors create a certain context for the listeners and viewers. News frames make certain facts meaningful, provide a context in which to understand issues, shape the inferences made, reinforce stereotypes, determine judgments and decisions, draw attention to some aspects of reality while obscuring other elements. The media frames in turn create reactions in the audience, relating to diagnosis of causes, attribution of responsibility, and so on (Baker, 2006).

In order to go into detail in analysing news item translation, we must remember that press translation is characterised by the imperative of quickness. The issue of speed that troubles any translator and translation in the real world, in the case of press translation, becomes an essential characteristic and not a secondary one. The issue of speed in the exploitation of translation is strongly linked to the issue of comprehension. This is aimed at giving attention to the target public: the listener to radio newscast needs to grasp it quickly, getting a sense of what the news item says straightaway. A news item is not meant to be re-read or pondered over several times, but should offer immediate comprehension. Unfortunately, in the field of translations, readability, comprehension and speed often end up simply as textual and cultural domestication (Venuti, 1995).

\section{Translation Loss}

As Hervey and Higgins (1992: 24) point out, the transfer of meaning from ST (Source Text) to TT (Target Text) necessarily involves a certain degree of translation loss. This is because a TT will always lack certain culturally relevant features that are present in the ST. An important corollary of this concept of translation loss is that it embraces any failure to replicate an ST exactly, whether this involves losing features in the TT or adding them. Hervey and Higgins (1992: 23) explain that this is due to the fact that backgrounds, shared knowledge, cultural assumptions and learnt responses of monolingual TL (Target language) speakers are inevitably culture-bound. Given this fact, SL (source language) speakers' responses to the ST are never likely to be replicated exactly by effects on members of a different culture. Even a small cultural distance between the ST audience and the TT audience is bound to produce a fundamental dissimilarity between the effects of the ST and those of the TT - such

effects can at best be similar in a global and limited sense; they can never be 
'the same'. As a result, Hervey and Higgins (1992) conclude that "if there is equivalence here, it is not an objective equivalence, because the translator remains the final arbiter of the imagined effects of both the ST and TT" (22-23). Under these circumstances, even a relatively objective assessment of 'equivalent effect' is hard to envisage.

Consequently, some questions arise because of the preceding claim: how do the Yoruba news-writers or 'arbiters' make their judgement regarding the equivalence? What ideology makes them choose to 'lose' something in order to achieve their 'gain'? What is their ultimate 'gain'? In order to answer these questions, we have to put them into a specific environment, taking into consideration the Yorubá culture and worldview as a whole.

\section{Theoretical Framework}

Theoretical models for translation studies today are a cluster of overlapping perspectives. There is no unified way of approaching the study of translation (Neubert \& Shreve, 2003: 6). Current notions of the nature of translation no longer see translation simply as a matter of source to target language rendering of one written text to another. This view is quite prevalent among non-translators and, for the purpose of this paper, this view must be tested against our findings for its veracity. In this regard, this study adopts André Lefevere's theory of rewriting (1992) which emphasises rewriting of original text to suit the need and the context in which the listening is taking place and the notions of patronage associated with this. The rationale for choosing this paradigm is that it captures the influence of the cultural environment in which translation takes place, and sees the translator as an involved agent who is influenced by his or her surrounding cultural environment.

\section{Data Presentation and Analysis}

Sixty-five concepts/official/professional titles extracted from one hundred news bulletins presented by five radio stations across the Yorubá-speaking states of Nigeria are examined. The radio stations are: The Broadcasting Corporation of Oyó State (BCOS), Òun State Broadcasting Corporation (OGBC), Radio Lagos, Olúyolé FM, and Paramount FM. The lexical items identified and examined are those that occur frequently in news presentations and whose meanings are critically tied to the context of the reports.

The data are presented and analysed as follows: 
Chart 1: Translation of Professional Terms>

\begin{tabular}{|c|c|c|c|c|c|c|}
\hline$S / N$ & ENGLISH & $\begin{array}{l}\text { BCOS } \\
\text { YORÙBÁ } \\
\text { TRANSLA- } \\
\text { TION }\end{array}$ & $\begin{array}{l}\text { OLÚYÒLÉ } \\
\text { F.M YORÙBÁ } \\
\text { TRANSLATION }\end{array}$ & $\begin{array}{l}\text { OGBC AB } \\
\text { YORÙBÁ } \\
\text { TRANSLATION }\end{array}$ & $\begin{array}{l}\text { RADIO } \\
\text { LAGOS } \\
\text { YORÙBÁ } \\
\text { TRANSLA- } \\
\text { TION }\end{array}$ & $\begin{array}{l}\text { PARA- } \\
\text { MOUNT F.M } \\
\text { YORÙBÀ } \\
\text { TRANSLA- } \\
\text { TION }\end{array}$ \\
\hline 1. & Manager & Ògá àgbà & Ògá àgbà & Olùdarí & Ògá Àgbà & Ògá Àgbà \\
\hline 2. & $\begin{array}{l}\text { Chief Ex- } \\
\text { ecutive } \\
\text { Officer }\end{array}$ & Alásè àgbà & Aláse àgbà & Olùdarí & Alásé, & Alásé, \\
\hline 3. & Provost & $\begin{array}{l}\text { Olóri/ògá àgbà } \\
\text { ilé-èkó èkósé } \\
\text { olùkóni }\end{array}$ & $\begin{array}{l}\text { Olóríògá àgbà } \\
\text { ilé-èkó èkósé } \\
\text { olùkóni }\end{array}$ & $\begin{array}{l}\text { Ògá àgbà fún ilé- } \\
\text { èkó olùkóni }\end{array}$ & $\begin{array}{l}\text { Ògá Àgbà } \\
\text { fún ilé-èkó } \\
\text { olùkóni }\end{array}$ & $\begin{array}{l}\text { Ògá Àgbà } \\
\text { fún ilé-èkó, } \\
\text { olùkóni }\end{array}$ \\
\hline 4. & Teacher & Olùkó-ni & Olùkó-ni & Olùkó, & Olùkó, & Olùkó, \\
\hline 5. & Rector & $\begin{array}{l}\text { Ògá àgbà ilé- } \\
\text { èkó gbogbonisse }\end{array}$ & $\begin{array}{l}\text { Ògá àgbà ilé-èkó, } \\
\text { gbogbonișe }\end{array}$ & $\begin{array}{l}\text { Ògá àgbà fún ilé- } \\
\text { èkó gbogbonisese }\end{array}$ & $\begin{array}{l}\text { Ògá àgbà } \\
\text { fún ilé-èkó, } \\
\text { gbogbonisese }\end{array}$ & $\begin{array}{l}\text { Ògá Àgbà } \\
\text { fún ilé-èkó, } \\
\text { gbogbonișe }\end{array}$ \\
\hline 6. & $\begin{array}{l}\text { Vice } \\
\text { Chancellor }\end{array}$ & $\begin{array}{l}\text { Gíwá/aláse àgbà } \\
\text { ilé-èkó, fásitì }\end{array}$ & $\begin{array}{l}\text { Gíwá/aláse àgbà } \\
\text { ilé-èkó fásitì }\end{array}$ & $\begin{array}{l}\text { Ògá àgbà fún ilé- } \\
\text { èkó fásitì }\end{array}$ & $\begin{array}{l}\text { Ògá àgbà fún } \\
\text { ilé-èkó fásiti }\end{array}$ & $\begin{array}{l}\text { Ògá àgbà fún } \\
\text { ilé- èkó fásitì }\end{array}$ \\
\hline 7. & Principal & $\begin{array}{l}\text { Ògá ilé-èkó } \\
\text { girama }\end{array}$ & $\begin{array}{l}\text { Ògá ilé-èkó } \\
\text { girama }\end{array}$ & $\begin{array}{l}\text { Ògá ilé-èkó gíga } \\
\text { girama }\end{array}$ & $\begin{array}{l}\text { Ògá ilé-èkó } \\
\text { gíga }\end{array}$ & $\begin{array}{l}\text { Ògá ilé-èkó } \\
\text { gíga }\end{array}$ \\
\hline 8. & Barrister & $\begin{array}{l}\text { Amófin-Akósé } \\
\text { mosé }\end{array}$ & $\begin{array}{l}\text { Amòfin-Akósé } \\
\text { mosé }\end{array}$ & Agbejórò & Agbejórò & Agbejórò \\
\hline 9. & Surgeon & $\begin{array}{l}\text { Dóḱità onisésé } \\
\text { abe }\end{array}$ & Dókítà onisé abe & Onísègùn abe, & Onísègùn abe & Onísègùn abe \\
\hline 10. & Editor & Olóotú ìroyìn & Olóotú ìroyin & Olóotú ìroyìn & Olóotú ìroyin & Olóòtú \\
\hline
\end{tabular}

The concepts in the table above are translated using loaded noun phrases. The word 'Manager' in (item number 1), a single word, is rendered as a noun phrase ogá àgbà (the senior/superior boss) in Yorubá by four stations. The word 'Editor' (item number 10) is translated as olootu' iroyin (the boss presiding over news). The words 'Rector' and 'Provost' (items number 3 and 5) are rendered in wordy noun phrases as olórí/ogá àgbà ilé-èkóséselukóni (the most senior boss in the College of Education) or ogá àgbà fún ilé-èkó gbogbonise (the most senior boss of the polytechnic). Apart from being long and wordy, the translations lack clarity. The word olootú in Yorubá can be used to signify leadership of any kind. The problem here is that it lacks precision. Other examples in which long-winded nominal paraphrases are employed for translation include 'Principal' (item number 7) ogá ilé-èko' girama (the boss for the Grammar School); 'Surgeon' (item number 9) dókità onisé abe (the doctor who 
works with the knife); 'Barrister' (item number 8) amojin akósé-mosé (the professional well-trained in the law).

Vague descriptive phrases such as ògá àgbà (the most senior boss), olor í (the head/leader) aláse (the wielder of authority), aláse àgbà (the most senior wielder of authority) are employed to represent a number of distinctive entities in English. This creates the problem referential confusion. For example, the difference in the referential imports of the positions of 'Manager' and 'Chief Executive Officer' (item numbers 1and 2) is blurred by the translation of both as 'ga' àgbà (the most senior boss) or of the difference in the positions of 'Rector', 'Provost', 'Vice-chancellor' (items numbers 3, 5 and 6) translated as ogá (boss) or aláse àgbà (the senior wielder of authority). The table below displays the items dealing with political ideologies / terminologies.

\section{Chart 2: Translation of Political Titles}

\begin{tabular}{|c|c|c|c|c|c|c|}
\hline $\mathrm{S} / \mathrm{N}$ & ENGLISH & $\begin{array}{l}\text { BCOS YORÙBÁ } \\
\text { TRANSLATION }\end{array}$ & $\begin{array}{l}\text { OLÚYÒLÉ } \\
\text { F.M YORÙBÁ } \\
\text { TRANSLATION }\end{array}$ & $\begin{array}{l}\text { OGBC AB } \\
\text { YORÙBÁ } \\
\text { TRANSLATION }\end{array}$ & $\begin{array}{l}\text { RADIO LAGOS } \\
\text { YORÙBÁ } \\
\text { TRANSLATION }\end{array}$ & $\begin{array}{l}\text { PARAMOUNT } \\
\text { F.M YORÙBÁ } \\
\text { TRANSLATION }\end{array}$ \\
\hline 1. & President & $\begin{array}{l}\text { Olórí orilè èdè/Āàre } \\
\text { orilè èdè }\end{array}$ & $\begin{array}{l}\text { Olórí orilè èdè/Äàre } \\
\text { orilè èdè }\end{array}$ & Aláse tảbí Olórí & Äàre & Äàre \\
\hline 2. & $\begin{array}{l}\text { Vice-Presi- } \\
\text { dent }\end{array}$ & Igbákeji Äàre, & Igbákeji Äàre & Igbákeji aláse & Igbákeji ààre & Igbákeji ààre, \\
\hline 3. & $\begin{array}{l}\text { Prime } \\
\text { Minister }\end{array}$ & Olóòtú ijoba & Olóotú ìjoba & Oloótú ijoba & Olóotú İjoba & Olóotú İjoba \\
\hline 4. & $\begin{array}{l}\text { Commis- } \\
\text { sioners }\end{array}$ & Komísónnnà & Komísónnà & Alábooójútó isé ó oba & Komísínnà & Komísínnà \\
\hline 5. & Senator & Sénátò & Sénátò & Așònin àgbà & Sénátò & Sénátò \\
\hline 6. & Honorable & Așòin & Așònin & Olólá & Olólá & Olólá \\
\hline 7. & $\begin{array}{l}\text { Senate } \\
\text { President }\end{array}$ & Äàre ilé asòfin àgbà & Äàre ilé așơfin àgbà & Äàre ilé așòin àgbà & $\begin{array}{l}\text { Äàre ilé aşòin } \\
\text { àgbà }\end{array}$ & $\begin{array}{l}\text { Olóri Ilé İgbìmò } \\
\text { Assơfin Àgbà }\end{array}$ \\
\hline 8. & $\begin{array}{l}\text { Speaker, } \\
\text { House of } \\
\text { Represen- } \\
\text { tative }\end{array}$ & Äàre ilé asơơin kékeré & Äàre ilé asòin kékeré & $\begin{array}{l}\text { Äàre ilé asòin } \\
\text { kékeré }\end{array}$ & $\begin{array}{l}\text { Äàre ilé asơfin } \\
\text { kékeré }\end{array}$ & $\begin{array}{l}\text { Olùdarí Ilé Asò- } \\
\text { fin Àpapò Kékeré }\end{array}$ \\
\hline 9. & Senate whip & Olórí Adámolékun & Olórí Adámolékikun & Olórí Adámolékẹun & $\begin{array}{l}\text { Olórí } \\
\text { Adámolékun }\end{array}$ & $\begin{array}{l}\text { Akójànu Ilé } \\
\text { İgbìmò Asòfin } \\
\text { Àgbà }\end{array}$ \\
\hline 10. & $\begin{array}{l}\text { Re-Run } \\
\text { Election }\end{array}$ & Àtúndì Ìbò & Àtúndì İbò & Àtúndì İbò & Àtúndì İbò & Àtúndì Ìbò \\
\hline 11. & Constituency & Ekkùn İdibò & Ekkùn İdibò & Ekkùn İdibò & Ekkùn İdìbò & Ekkùn İdibò \\
\hline 12. & $\begin{array}{l}\text { Primary } \\
\text { Election }\end{array}$ & Ètò İdibò abẹlé & Ètò İdibò abélé & Ètò İdibò abélé & Ètò İdibò abẹlé & İdibò Abélé \\
\hline 13. & Bills & İwé Òfin & İwé Òfin & İwé Òfin & İwé Òfin & Àbá Òfin \\
\hline 14. & Motions & Àbá dơfin & Àbá dòfin & Àbá dòfin & Àbá dòfin & Àbá \\
\hline 15. & $\begin{array}{l}\text { Running } \\
\text { Mate }\end{array}$ & $\begin{array}{l}\text { Igbákeji òndije } \\
\text { dupo }\end{array}$ & $\begin{array}{l}\text { Igbákeji ondí̀je } \\
\text { dupo }\end{array}$ & $\begin{array}{l}\text { Igbákeji òndíje } \\
\text { dupo }\end{array}$ & $\begin{array}{l}\text { Igbákeji ondije } \\
\text { dupo }\end{array}$ & Olùbádíje \\
\hline
\end{tabular}


Concepts like 'President' (item number 1), 'the Senate President' (item number 7) and 'the Speaker of the House of Representatives' (item number 8) are all translated with the modifier àare, (the president): àare, orilè èdè (president of the nation), àare, ile asofin àgbà (president of the senior legislative chamber/house) and àare ilé asofin kékeré (president of the junior legislative chamber). Moreover, the President (i.e., the President of the nation) is confusingly referred to as äare (president), olorí orilè èdè (the head of nation/state) or aláse orilè èdè (the wielder of authority of the nation/state). It is difficult to say whether the problem arises from an inherent inadequacy in the resources of the Yoruba language or from limited competence on the part of the translators.

The translation of the Senate as ile asófin àgbà and the House of Representatives as ilé asòfin kékeré, contrasting àgbà (senior or higher or elder or greater) with kékeré (smaller, junior, lower) fails to differentiate the functions of the two legislative chambers, thus creating the misconception in Yoruba listeners that the function of law making being performed by the Senate is superior to the one being performed by the House of Representatives, an evaluation members of the latter are likely to find offensive. This translation requires more serious re-evaluation in view of the fact that Nigerians are sensitive to matters of titles and ranking.

Chart 3: Translation of Official Titles

\begin{tabular}{|c|c|c|c|c|c|c|}
\hline $\mathrm{S} / \mathrm{N}$ & ENGLISH & $\begin{array}{l}\text { BCOS YORÙBÁ } \\
\text { TRANSLATION }\end{array}$ & $\begin{array}{l}\text { OLÚYÒLÉ } \\
\text { F.M YORÙBÁ } \\
\text { TRANSLATION }\end{array}$ & $\begin{array}{l}\text { OGBC AB } \\
\text { YORÙBÁ } \\
\text { TRANSLATION }\end{array}$ & $\begin{array}{l}\text { RADIO LAGOS } \\
\text { YORÙBÁ } \\
\text { TRANSLATION }\end{array}$ & $\begin{array}{l}\text { PARAMOUNT } \\
\text { F.M YORÙBÁ } \\
\text { TRANSLATION }\end{array}$ \\
\hline 1. & $\begin{array}{l}\text { Head of } \\
\text { Depart- } \\
\text { ment }\end{array}$ & Olórí èka & Olórí èka & Olórí èka èkó & Olórí ẹka èkó, & Olórí èka èkó \\
\hline 2. & $\begin{array}{l}\text { Course } \\
\text { Advisor }\end{array}$ & $\begin{array}{l}\text { Olùbánidámò̀àn } \\
\text { ètò èkó }\end{array}$ & $\begin{array}{l}\text { Olùbánidámòràn } \\
\text { ètò èkó }\end{array}$ & $\begin{array}{l}\text { Olùbánidámò̀àn } \\
\text { èkó }\end{array}$ & $\begin{array}{l}\text { Olùbánidámò̀àn } \\
\text { èkó }\end{array}$ & $\begin{array}{l}\text { Olùbánidámòràn } \\
\text { èkó }\end{array}$ \\
\hline 3. & Chancellor & Olủbèwò àgbà & Olủbèwò àgbà & Baba ìsalè & Baba isalè & Baba isàlè \\
\hline 4. & Professor & Ojògbón & Ojògbón & Ojògbón & Ojògbón & Ojògbón \\
\hline 5. & Proprietor & Olùdásílè & Olùdásílè & $\begin{array}{l}\text { Olùdásilè } \\
\text { \{okuunrin\} }\end{array}$ & Olùdásílè & Olùdásílè \\
\hline 6. & Proprietress & Olùdásílè & Olùdásílè & $\begin{array}{l}\text { Olùdásílè } \\
\text { (obinnin) }\end{array}$ & Olùdásílè & Olùdásílè \\
\hline 7. & Secretary & Akòwé & Akòwé & Akòwé & Akờwé & Akờwé \\
\hline 8. & Registrar & Akòwé àgbà & Akờcé àgbà & Akơwé & Akờwé Àgbà & Akờwé Àgbà \\
\hline 9. & Journalist & $\begin{array}{l}\text { Oníròyin/ } \\
\text { akòroyin }\end{array}$ & $\begin{array}{l}\text { Oníròyin/ } \\
\text { akòroyin }\end{array}$ & Akoroyin & Akoroyin & Akorroyin \\
\hline 10. & Justice & Onídaàjó & Onídaàjó́ & İdájó & Onídaàjó & Onídàájó \\
\hline 11. & Judge & Adájó & Adájó & Adájó & Adájó & Adájó \\
\hline 12. & Councillor & Kánsélò & Kánsélı̀, & Kánsélò & Kánsélò & Kánsélò \\
\hline
\end{tabular}




\begin{tabular}{|c|c|c|c|c|c|c|}
\hline 13. & Dean & Olórí eka èto èkó & Olóri ekka èto èkó & Ògá àgbà léka ẹkó & Ògá àgbà léka èkó & Ògá àgbà léka èkó \\
\hline 14. & $\begin{array}{l}\text { Doctorate } \\
\text { Degree }\end{array}$ & Oyè òmòwé & Oyè òmòwé & Oyè ìmò èkó, & Oyè òmòwé & Oyè òmòwé \\
\hline 15. & Profession & $\begin{array}{l}\text { Isé èniyàn yàn } \\
\text { láyòisé ise }\end{array}$ & $\begin{array}{l}\text { Isé èniyàn yàn } \\
\text { lánòisé ise }\end{array}$ & Ișé tí a yàn láàyò & Ișé tí a yàn láàyò & Isé tí a yàn láàyò \\
\hline 16. & Accountant & Olùsisiro owó & Olùșirò owó & Olùsirio owó & Olùsirò owó & Olùsirirò owó \\
\hline 17. & Nurse & Olùtójú alâisàn & Olùtójú alâisàn & Olùtójú alâisàn & Olùtójú aláisàn & Olùtójú alâisàn \\
\hline 18. & Judge & Adájó & Adájó & Adájó & Adájó & Adájó \\
\hline 19. & Prince & Omooba & Omooba & $\begin{array}{l}\text { Omooba } \\
\text { (okünrin) }\end{array}$ & $\begin{array}{l}\text { Omooba } \\
\text { (okünrin) }\end{array}$ & $\begin{array}{l}\text { Omooba } \\
\text { (okünrin) }\end{array}$ \\
\hline 20. & Chief & Olóyè & Olóyè & Olóyè & Olóyè & Olóyè \\
\hline 21. & $\begin{array}{l}\text { Mister } \\
(\mathrm{Mr})\end{array}$ & Ògbéni & Ògbéni & Ògbéni & Ògbéni & Ògbéni \\
\hline 22. & Evangelist & Ajíhìnrere & Ajíhinrere & Àlưfá ìjo & Ajíhìnrere & Ajíhinrere \\
\hline 23. & $\begin{array}{l}\text { General } \\
\text { Overseer }\end{array}$ & Alàkoóso àgbà & Alàkooóso àgbà & Alàkoóso àgbà & Alàkòóso & Alàkòóso \\
\hline 24. & Reverend & Eni òwò & Eni òwò & Eni òwò & Eni òwò & Eni òwò \\
\hline 25. & Minister & İránńsé Olúwa & İránnssé Olúwa & İránńsé Olúwa & İránńsé Olúwa & İránn'sé Olúwa \\
\hline 26. & Cardinal & Kádínà & Kádínà & Kádínà & Kádínà & Kádínà \\
\hline 27. & Comrade & Kómíréèdì & Kómírèèdi & Kómíréèdì & Kómírèèdi & Kómírèdì \\
\hline 28. & Sergeant & Sájéntì & Sájéntì & Sáéñ̀ti & Sájéntì & Sájéntì \\
\hline 29. & Inspector & Ripétò & Ripétò & Ripétò & Ripétò & Ripétò \\
\hline 30. & Deacon & Díákónì & Díákónì & Díákónì & Díákónì & Díákónì \\
\hline 31. & Million & Miliónù & Míliónù & Míliónù & Míliónù & Míliónù \\
\hline 32. & Colonel & Ògágun & Ògágun & Ògágun & Ògágun & Ògágun \\
\hline 33. & General & Ògágun & Ògágun & Ògágun & Ògágun & Ògágun \\
\hline 34. & Admiral & Ògágun & Ògágun & Ògágun & Ògágun & Ògágun \\
\hline 35. & Chaplain & İránńsé Olórun & İránnssé Olórúrun & İránnssé Olórun & İránnssé Olórun & İránńsé Olı́rórun \\
\hline 36. & Bishop & Bísóó,bù & Bísóóóbù & Bísóóóbù & Bísóóóbù & Bísóóóbù \\
\hline 37. & Pastor & İránńsé Olórun & İránńsé Olórun & İránńsé Olórun & İránńsé Olórun & İránńsé Olórun \\
\hline 38. & Elder & Alàgbà & Alàgbà & Alàgbà & Alàgbà & Alàgbà \\
\hline 39. & Aunt & Ègbón Obìnrin & Ègbón Obinrin & Ègbón Obinnin & Ègbón Obinrin & Ègbón Obìnrin \\
\hline 40. & Uncle & Ègbón Okùnrin & Ègbón Okùnrin & Ègbón Okùnrin & Ègbón Okùnrin & Ègbón Okùnrin \\
\hline
\end{tabular}


There are cases of direct borrowing and nativization of foreign words by the local news-writer in this section. Rewriting of words like 'Comrade' (item number 28) as Kómíréedi, 'Councillor' (item number 12) as Kánsélò, 'Sergeant' (item number 29) as Sájéntit, 'Inspector'; (item number 30) as Ripétó, 'Deacon' (item number 31) as Diákóni, 'Cardinal' (item number 27) as Kádinà, 'Million' (item number 32) as Miliónu is an interesting phenomenon.

\section{Conclusion}

The paper has subjected the translations of some official titles and concepts by broadcast media in the Yorubá-speaking area of Nigeria to scrutiny against the background of the fact that the two languages involved, English and Yorubá, are embedded in and convey different cultural values. Translations are usually notoriously challenging and accuracy is often difficult to attain. Not surprisingly, many of the translated concepts suffer lack of fidelity to the original versions. Many of the translations betray vagueness, ambiguity, indeterminate reference and even unwitting distortions, qualities that are inconsistent with the principles of mass communication. Ideally, mass communicated messages are crafted in such a way that they display absolute clarity.

This situation places a high responsibility on the news translators, calling for a re-evaluation of the translation strategies adopted so far. Sloppiness and mental indolence must give way to a critical engagement with the texts and an acute sense of accuracy and appropriateness to attain more respectable versions of the translations than hitherto obtain.

\section{References}

Akio, Fryii. (1988). “News translation in Japan”. In Meta 33 (1), 32-37.

Baker, Mona. (2006). Translation and Conflict: A Narrative Account. London: Routledge.

Bassnett, Susan. (1999). “The Cultural Turn in Translation Studies." In Constructing Cultures - Essays on Literature Translation, Susan Bassnett and André Lefevere (eds.), Pp. 123-40. Clevedon: Multilingual Matters.

Bassnett, Susan and André Lefevere. (1998). Constructing Cultures: Essays on Literary Translation. Clevedon: Multilingual Matters.

Bielsa, Esperança, and Susan Bassnett. (2009). Translation in Global News. New York: Routledge.

Catford, J.C. (1965). A Linguistic Theory of Translation. London: Routledge. Caimotto, M. Cristina. (2010). "Translating Foreign Articles with Local Implications: A Case Study." In Poltical Discourse, Media and Translation, Christina Schäffner and Susan Bassnett, (eds.). Pp. 76-93. Newcastle-upon-Tyne: Cambridge Scholars. 
Chesterman, Andrew. (2000). "A Causal Model for Translation Studies." In Intercultural Faultlines: Research Models in Translation Studies I; Textual and Cognitive Aspects. Maeve Olohan, (ed.). Northampton MA: St. Jerome. Pp. 15-27.

Clausen, Lisbeth. (2004). 'Localizing the Global: 'Domestication' Processes'. In International News Production. Media, Culture \& Society 26, no. 1. Pp. 25-44.

Dubois, Danièle (ed.). (1997). Catégorisation et cognition. De la perception au discours. Paris: Édition Kimé.

Entman, R.M. (1991). 'Framing US Coverage of International News. Contrast in Narratives of the KAL and Iran Air Incidents', Journal of Communication 41 (4), Pp. 6-27.

Fillmore, Charles. (1977). 'Scenes-and-frames Semantics'. In Antonio Zampolli (ed.). Linguistic Structure Processing. Amsterdam: North Holland, Pp. 55-88.

Gambier, Yves. \& Henrik, Gottlieb. (eds.). (2001). (Multi) Media Translation. Concepts, Practices and Research. Philadelphia: John Benjamins.

Gentzler, Edwin. (2001). Contemporary Translation Theories. 2nd Ed. New York: Routledge

Goffman, Erving. (1974). Frame Analysis. New York: Harper \& Row.

Haj Mohammadi, Ali. (2005). 'Translation Evaluation in a News Agency'. In Perspectives 13 (3). Pp. 215-224.

Hervey, Sándor, and Ian Higgins. (1992). Thinking Translation. A Course in Translation Method: French to English. New York: Routledge.

Hursti, Kristian. (2001). 'An Insider's View on Transformation and Transfer in International News Communication' In Helsinki English Studies, Electronic journal http://www.eng.helsinki.fi/hes/Translation/insiders_view1.htm.

Kelly, Don. (2000). A Social Constructivist Approach to Translator Education. Empowerment from Theory to Practice. Manchester: St. Jerome Publishing. Lefevere, Andre. (1998). 'Translation Practice(s) and the Circulation of Cultural Capital: Some Aeneids in English'. In Susan Bassnett (ed.). Constructing Cultures: Essays on Literary Translation. Clevedon: Multilingual Matters. Lefevere, André. (1992). Translation, Rewriting and the Manipulation of Literary Fame. London: Routledge.

Lefevere, André. and Susan, Bassnett. (1990). 'Introduction: Proust's Grandmother and the Thousand and One Nights: The Cultural Turn in Translation Studies'. In Translation, History and Culture. Susan Bassnett and André Lefevere (eds.). 1-13. London: Pinter.

Neubert, Albert. and Gregory, Shreve. (2003). Translation as Text. Kent: Kent State University Press, 1992. 
Schank, R. C. \& A.P. Abelson. (1977). Scripts, Plans, Goals and Understanding. Hillsdale: L. Erlbaum.

Schäffner, Christina. (2001). 'The Skopos Theory'. In Routledge Encyclopedia of Translation Studies. Mona Baker \& Kirsten Malmkjar (eds.). New York: Routledge. Pp. 235-238.

Schäffner, Christina, and Susan Bassnett. (2010). 'Introduction: Politics, Media and Translation: Exploring Synergies'. In Political Discourse, Media and Translation, Christina Schäffner and Susan Bassnett (eds.). Newcastle-upon-Tyne: Cambridge Scholars. Pp. 1-31.

Toury, Gideon. (1995). Descriptive Translation Studies and Beyond. Philadelphia: Benjamins, Pp. 241 - 258.

Van Dijk, Teun A. (1998). 'Opinions and Ideologies in the Press'. In Approaches to Media Discourse. Allan Bell and Peter Garrett (eds.). Oxford: Blackwell. Pp. 21-63.

Venuti, Lawrence. (1995). The Translator's Invisibility: A History of Translation. London: Routledge. 